This is the accepted version of a chapter that was published in the book 'The Plant

Endoplasmic Reticulum' ed. Chris Hawes and Verena Kriechbaumer (2017)

Running head: Microsome preparation

Corresponding author:

Dr Verena Kriechbaumer

Plant Cell Biology, Biological and Medical Sciences, Oxford Brookes University, OX3 0BP

Oxford, United Kingdom

Email: vkriechbaumer@brookes.ac.uk 


\title{
ER Microsome Preparation in Arabidopsis thaliana
}

Verena Kriechbaumer

Plant Cell Biology, Biological and Medical Sciences, Oxford Brookes University, OX3 OBP Oxford, UK

\begin{abstract}
Microsomes are vesicles derived from the endoplasmic reticulum (ER) when cells are broken down in the lab. These microsomes are a valuable tool to study a variety of ER functions such as protein and lipid synthesis in vitro.

Here we describe a protocol to isolate ER-derived microsomes Arabidopsis thaliana seedlings and exemplify the use of these purified microsomes in enzyme assays with the auxin precursors tryptophan (Trp) or indole-3-pyruvic acid (IPyA) to quantify auxin synthetic capacity in microsomal and cytosolic fractions.
\end{abstract}

Key words: endoplasmic reticulum, microsomal fraction, enzyme assays, arabidopsis

\section{Introduction}

Microsomes are generally described as vesicle-like structures with a diameter of 100-200 nm that are formed from pieces of the endoplasmic reticulum (ER) after eukaryotic cells are broken down experimentally (Fig. 1); hence microsomes are not found in healthy living cells. Microsomes are still capable of ER-functions such as protein synthesis, protein glycosylation, $\mathrm{Ca}^{2+}$ uptake, and lipid synthesis and can be used to study all these functions in a test tube (1). Therefore microsomes have found use in a plethora of experimental approaches and studies. 
Microsomes are purified from other cell compartments and membranes by differential centrifugation at $100,0000 \mathrm{~g}$. Whole cells, nuclei and mitochondria pellet at $10,000 \mathrm{~g} \mathrm{(2)}$ and chloroplasts already at $1000 \mathrm{~g}(3,4)$.

In his publication on the "constitution of protoplasm" Albert Claude named microsomes in 1943 (5) to distinguish these "small granules of undefined nature". He then used this fractionation technique to determine the localisation of nucleic acid in leukemic cells (6). Current applications and use of microsomes for research are for -amongst various othersexample the areas of lipid secretion (7), P450 assays (8), or auxin biosynthesis $(9,10,11)$.

A common source for microsomes are dog pancreas cells (12) or rabbit reticulocyte lysate (13).In plants microsomes wheat germ is a common source (14) or can be purified from purified from soybeans (15).

Here we describe the isolation of microsomes from Arabidopsis thaliana seedlings (adapted from $9,10,11)$.

\section{Materials}

2.1 Stock solutions (see Note 1)

2.1.1 For microsomal preparation:

1. M TEA-HOAc, $\mathrm{pH} 7.5$

2. $2 \mathrm{M} \mathrm{KOAc}, \mathrm{pH} 7.5$

3. $0.1 \mathrm{M} \mathrm{Mg}(\mathrm{OAc})_{2}$

4. $1 \mathrm{M}$ Sucrose

5. $1 \mathrm{M} \mathrm{DTT}$

6. $0.5 \mathrm{M}$ EDTA 
2.1.2 For IAA quantification:

1. $1 \mathrm{M}$ Tris- $\mathrm{HCl}, \mathrm{pH} 8.0$

2. $1 \mathrm{M} \mathrm{Na}_{2} \mathrm{CO}_{3}$

3. $0.1 \mathrm{M} \mathrm{NADPH}$

4. $0.1 \mathrm{M} \mathrm{FAD}$

5. $0.1 \mathrm{M}$ indole-3-pyruvic acid (IPyA)

6. $1 \mathrm{M}$ Tryptophan (Trp)

\subsection{Buffers}

1. Buffer $\mathrm{A}: 25 \mathrm{mM}$ TEA-HOAc (pH 7.5), $50 \mathrm{mM} \mathrm{KOAc}$, $(\mathrm{pH} 7.5), 5 \mathrm{mM} \mathrm{Mg}(\mathrm{OAc})_{2}, 0.25 \mathrm{M}$ Sucrose, 4mM DTT.

2. Buffer B: 100 mM TEA-HOAc (pH 7.5), 20 mM EDTA.

3. Buffer C: 25 mM TEA-HOAc (pH 7.5), $25 \mathrm{mM} \mathrm{KOAc} \mathrm{(pH} \mathrm{7.5),} 2 \mathrm{mM} \mathrm{Mg}(\mathrm{OAc})_{2}, 0.5 \mathrm{M}$ Sucrose, 4 mM DTT.

4. Buffer D: 25 mM TEA-HOAc (pH 7.5), $0.25 \mathrm{M}$ Sucrose, $1 \mathrm{mM}$ DTT.

\subsection{Equipment}

1. Porcelain mortar \& pestle

2. Glass bottles for buffers

3. Cheese cloth

4. Refrigerated table centrifuge

5. Ultracentrifuge with swing-out rotor (e.g. SW41, Beckman Coulter)

6. Ultracentrifuge corex tubes

7. $2 \mathrm{ml}$ Potter-Elvehjem homogenizer with glass rod

8. water bath $\left(37^{\circ} \mathrm{C}\right)$

9. Speed-vac

10. Nanodrop to determine protein concentration 


\section{Methods}

3.1 Endoplasmic reticulum (ER) microsome preparation

(This part of the procedure will take between 3 and $4 \mathrm{~h}$ depending on sample size.)

1. All steps are carried out on ice or at $4^{\circ} \mathrm{C}$ unless indicated otherwise.

2. All buffers, tubes etc. used in the procedure should be pre-cooled (see Note 2).

3. $5 \mathrm{~g}$ of arabidopsis seedling tissue ( 7 days after germination, see Note $3, \mathbf{4}, \mathbf{5}$ ) are ground to fine powder in liquid nitrogen using a pre-cooled mortar and pestle.

4. The powder is then homogenized in $4 \mathrm{ml}$ of ice-cold buffer $\mathrm{A}$ and transferred into a $50 \mathrm{ml}$ falcon tube.

5. $4 \mathrm{ml}$ of ice-cold buffer $\mathrm{B}$ are added to the tube and the suspension is incubated on ice for $10 \mathrm{~min}$. Then the homogenate is centrifuged at $1,000 \times \mathrm{g}$ for $10 \mathrm{~min}$ at $4^{\circ} \mathrm{C}$. The resulting supernatant is poured over 4 layers of cheese cloth into a fresh falcon tube. At this step, the resulting extract is considered total plant extract for later enzymatic assays. The extract is centrifuged again at $4,500 \times \mathrm{g}$ for $25 \mathrm{~min}$ at $4^{\circ} \mathrm{C}$.

6. A $4 \mathrm{ml}$ sucrose cushion (buffer $\mathrm{C}$ ) is layered on the bottom of ultracentrifuge corex tubes.

7. The $8 \mathrm{ml}$ of plant suspension is layered on top of this sucrose cushion by slightly angling the tube and carefully and slowly pipetting the suspension at the side of the tube. The tube is centrifuged for $90 \mathrm{~min}$ at $93,000 \times g$ (ultracentrifuge with swing-out rotor e.g. SW41).

8. The resulting pellet is removed from the ultracentrifuge tube if necessary with $20 \mu \mathrm{l}$ of buffer $\mathrm{D}$ and transferred to a $2 \mathrm{ml}$ Potter-Elvehjem homogenizer. The supernatant is kept and used as cytosolic extract in later IAA quantifications.

9. The final pellet was resuspended in $200 \mu \mathrm{l}$ of buffer $\mathrm{D}$ using a glass rod and a $2 \mathrm{ml}$ Potter-Elvehjem homogenizer. Protein content is measured using a Nanodrop. Freshly prepared microsomes should be used for enzymatic assays straight away (see Note 6).

\subsection{Purity of microsomes}

To check for the purity of the microsomal fraction both the microsomal as well as the cytosolic 
fraction were probed with an anti-HSP70 antibody detecting cytosolic heat shock protein 70 (Fig. 3). The HSP70 band was only detected in the cytosolic fraction indicating a rather pure microsomal fraction.

Further purity test using immunoblot analysis could include testing for the presence of plasma membrane or mitochondrial proteins in the microsomal fraction.

\subsection{Example for microsomal enzymatic tests}

The YUC-route of auxin biosynthesis is a two-step process (Fig. 2): In arabidopsis TAA-proteins (Tryptophan Aminotransferase of Arabidopsis). TAA1, TAR1, and TAR2 are converting tryptophan (Trp) to indole-3-pyruvic acid (IPyA) (16) which is then converted by YUC proteins to IAA (YUC1-11) (17). It was shown that TAR2, YUC4.2, 5, 7, 8, and 9 are located in the ER, whereas TAA1 and YUC1, 2, 3, 6, and 11 are located to the cytosol (10). Enzymatic activity tests (100 $\mu$ l total volume) with microsomal and cytosolic fractions were carried out in the following manner:

1 In $2 \mathrm{ml}$ Eppendorf tubes mix carefully: $20 \mu \mathrm{l}$ of microsomal or cytosolic extract, $1 \mathrm{mM}$ NADPH, $100 \mu \mathrm{M}$ FAD, $100 \mu \mathrm{M}$ IPyA or Trp (depending on experimental interest).

$2100 \mathrm{mM}$ Tris- $\mathrm{HCl}(\mathrm{pH} 8.0)$ up to a total volume of $100 \mu \mathrm{l}$.

3 The assays are incubated for $1 \mathrm{~h}$ in a $37^{\circ} \mathrm{C}$ water bath and snap-frozen in liquid nitrogen straight after the incubation time.

4 At this stage the assays can be stored at $-20^{\circ} \mathrm{C}$ before the IAA analysis is carried out.

\subsection{Auxin biosynthetic capacity in arabidopsis microsomes.}

Representative data for the conversion of tryptophan and IPyA to IAA in arabidopsis seedlings shown in Figure 4 (10).

\section{Notes}

1. Filter buffers $1-4$ through $0.45 \mu \mathrm{m}$ syringe filters. Add DTT from $1 \mathrm{M}$ stock fresh prior to use. 
2. Pre-chill tubes, glassware, buffers, centrifuges etc and keep your samples on ice as much as possible.

3. Tissue: depending on the biological question instead of using whole seedlings for the microsomal preparation it can e.g. be distinguished between root and shoot or other ages and developmental stages can be used.

4. This preparation has also been successfully used for maize (9) and tobacco tissues (unpublished).

5. Collect plant material straight into a chilled falcon tube that is kept on ice and try to collect the material as quickly as possible.

6. Where possible timewise freshly prepared microsomes should be used for enzyme assays. Freezing in $20 \%$ glycerol for later assays is possible but not recommended.

\section{Acknowledgements}

This work was supported by a research scholarship from the Korean Federation of Science and Technology Societies (KOFST) awarded to Dr Verena Kriechbaumer and the British Biotechnology and Biological Sciences Research Council (grant no. BB/J004987/1 research grant) awarded to Prof Chris Hawes.

\section{References}

1. Alberts B, Johnson A, Lewis J, Morgan D, Raff M, Roberts K, Walter P (2014) Molecular Biology of the Cell. $6^{\text {th }}$ Edition, Garland Science

2. Nagahashi J, Hiraike K (1982) Effects of centrifugal force and centrifugation time on the sedimentation of plant organelles. Plant Physiol 69:546-548

3. Tobin AK, Bowsher CG (2004) Subcellular fractionation of plant tissues: isolation of plastids and mitochondria. Methods Mol Biol 244:53-63

4. Kriechbaumer V, Shaw R, Mukherjee J, Bowsher CG, Harrison AM, Abell BM (2009) 
Subcellular distribution of tail-anchored proteins in Arabidopsis. Traffic 10:1753-1764

5. Claude A (1943) The constitution of protoplasm. Science 97:451-456

6. Claude A (1944) The constitution of mitochondria and microsomes, and the distribution of nucleic acid in the cytoplasm of a leukemic cell. J Exp Med 144 80:19-29

7. Yao Z, Zhou H, Figeys D, Wang Y, Sundaram M (2013)Microsome-associated lumenal lipid droplets in the regulation of lipoprotein secretion. Curr Opin Lipidol 24:160-170

8. Clausen M, Kannangara RM, Olsen CE, Blomstedt CK, Gleadow RM, Jørgensen K, Bak S, Motawie MS, Møller BL (2015) The bifurcation of the cyanogenic glucoside and glucosinolate biosynthetic pathways. Plant J 84:558-573

9. Kriechbaumer V, Seo H, Park WJ, Hawes C (2015) Endoplasmic reticulum localization and activity of maize auxin biosynthetic enzymes. J Exp Bot 66:6009-6020

10. Kriechbaumer V Botchway SW, Hawes C (2016a) Localization and interactions between Arabidopsis auxin biosynthetic enzymes in the TAA/YUC-dependent pathway. J Exp Bot $67: 4195-207$

11. Kriechbaumer V (2016b) ER Microsome Preparation and Subsequent IAA Quantification in Maize Coleoptile and Primary Root Tissue Bio-protocol 6(9):e1805

12. Walter $P$, Blobel $G$ (1983) Preparation of microsomal membranes for cotranslational protein translocation. Methods Enzymol 96:84-89

13. Jackson R, Hunt T (1983) Preparation and use of nuclease-treated rabbit reticulocyte lysates for the translation of eukaryotic messenger RNA. Methods Enzymol 96:50-74 14. Erickson AH, Blobel G (1983) Cell-free translation of messenger RNA in a wheat germ system. Methods Enzymol 96:38-50 
15. Abell BM, Holbrook L.A, Abenes M, Murphy DJ, Hills MJ, Moloney MM (1997) Role of the proline knot motif in oleosin endoplasmic reticulum topology and oil body targeting. Plant Cell $9: 1481-1493$

16. ZhaoY, Christensen SK, Fankhauser C, Cashman JR, Cohen JD, Weigel D, Chory J (2001) A role for flavin monooxygenase-like enzymes in auxin biosynthesis. Science 291:306-309

17. Stepanova AN, Robertson-Hoyt J, Yun J, Benavente LM, Xie DY, Dolezal K, Schlereth A, Jürgens G, Alonso JM (2008) TAA1-mediated auxin biosynthesis is essential for hormone crosstalk and plant development. Cell 133:177-191 


\section{Figure legends}

Figure 1: Schematic representation of microsome purification.

Figure 2. Subcellular compartmentation of auxin biosynthesis in Arabidopsis thaliana.

(A) YUC-route of auxin biosynthesis in arabidopsis. ER-located enzymes are labeled in blue, cytosolic enzymes in green. (B) Confocal localization for two enzymes in the first step of IAA biosynthesis. TAA1 is present in the cytosol, whereas TAR2 shows ER-location.

Figure 3. Immunoblot analysis for purity of microsomal fractions. Microsomal (M) and cytosolic (C) fractions were tested for heat shock protein 70 (HSP70) proteins using immunoblot analysis. $100 \mu \mathrm{g}$ of protein from each fraction were probed with anti-HSP70 antibodies (1:1000) recognizing the cytosolic HSP70.

Figure 4. Auxin biosynthetic capacity in arabidopsis seedlings. Enzymatic conversion of tryptophan to IAA by microsomal (Microsome) fractions or cytosolic (Cytosol) fractions from arabidopsis seedlings $7 \mathrm{~d}$ after germination. Standard errors are indicated. $\mathrm{n}=3$. 